\title{
SECONDARY HYPERALDOSTERONISM AND HYPERTENSION
}

\section{AUTHORS}

Prof. dr Slavica Pajović

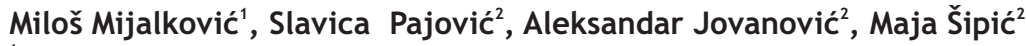

${ }^{1}$ Cardio Medica Polyclinic, Nis

${ }^{2}$ University of Priština, Faculty of Medicine, Kosovska Mitrovica

\section{SUMMARY}

Introduction: Arterial hypertension is a major cardiovascular risk factor affecting about $10-40 \%$ of the adult population. Secondary endocrine hypertension most often results from excessive aldosterone secretion. Complications related to excessive aldosterone secretion include atrial fibrillation, myocardial infarction, myocardial fibrosis, left ventricular hypertrophy, stroke, and increased cardiovascular mortality.

Case report: This report presents a hypotensive woman with hypertensive reactions, newly diagnosed unilateral hyperplasia of the left adrenal gland and secondary hyperaldosteronism. Due to good blood pressure and normalized electrolyte status as a result of antihypertensive drug therapy and absence of damage to target organs, surgical treatment of unilateral adrenal hyperplasia was postponed.

Conclusion: In case of midlife and late-life hypertension, it is necessary to consider a cause in the patient's endocrine system. Key words: hyperaldosteronism, unilateral adrenal hyperplasia, hypertension

\section{SRPSKI}

\section{SEKUNDARNI HIPERALDOSTERONIZAM I HIPERTENZIJA}

Miloš Mijalković ${ }^{1}$, Slavica Pajović ${ }^{2}$ Aleksandar Jovanović ${ }^{2}$, Maja Šipić

${ }^{1}$ Poliklinika Kardiomedica, Niš

${ }^{2}$ Univerzitet u Prištini, Medicinski fakultet, Kosovska Mitrovica

\section{SAŽETAK}

Uvod: Arterijska hipertenzija je glavni faktor kardiovaskularnog rizika koji pogađa oko 10-40\% odraslog stanovništva. Sekundarna endokrina hipertenzija najčešće nastaje usled prekomerne sekrecije aldosterona. Komplikacije prekomerne eksrecije aldosterona su atrijalna fibrilacija, infarkt miokarda, miokardna fibroza, hipertrofija leve komore, moždani udar,

Prikaz slučaja: U radu je prikazana hipotenzivna pacijentkinja sa hipertenzivnim reakcijama, novootkrivenom unilateralnom hiperplazijom leve nadbubrežne žlezde i sekundarnim hiperaldosteronizmom. Zbog dobre kontrole krvnog pritiska i normalizacije elektrolitnog statusa na medikamentnoj antihipertenzivnoj terapiji, odsustva oštećenja ciljnih organa, odloženo je operativno lečenje unilateralne adrenalne hiperplazije.

Zaključak: U cilju postavljanja pravilne dijagnoze i terapije hipertenzije u srednjem i kasnijem žovotnom dobu, neophodno je razmotriti mogućnost postojanja uzroka u endokrinom sistemu pacijenta.

Ključne reči: hiperaldosteronizam, unilateralna adrenalna hiperplazija, hipertenzija. 


\section{INTRODUCTION}

Arterial hypertension is a major cardiovascular risk factor affecting about $10-40 \%$ of the adult population, and is slightly more common in men than women. Secondary hypertension is a disease with a known cause and occurs in about $5 \%$ of cases. In endocrine hypertension, one of the most common causes is primary hyperaldosteronism $(1,2)$.

Primary hyperaldoseronism was first described by Jerome W. Conn in 1954. Its main characteristics include autonomous aldosterone production from the glomerular zone of the adrenal cortex and secondary renin activity suppression with the development of hypertension and hypokalemic alkalosis (3). Pathophysiologically increased reabsorption of sodium and circulating fluid volume leads to increased peripheral vascular resistance and development of hypertension. Apart from adrenal cortex tumors, the most common causes are bilateral adrenal hyperplasia, followed by unilateral adrenal hyperplasia, ectopic aldosteroneproducing tumor, aldosterone-producing adrenocortical carcinoma and familial hyperaldosteronism type I (4).

Secondary hyperaldosteronism occurs due to renal hypoperfusion and consequent over-activation of the reninangiotensin-aldosterone system, and is characterized by increased aldosterone levels, increased renin, hypokalemia, hyponatremia, or normal sodium levels. Transient activation of the renin-angiotensin-aldosterone system may occur physiologically due to hypovolemia. It also occurs with renal artery stenosis (atherosclerosis or fibromuscular dysplasia), renal vasoconstriction, left-sided congestive heart failure, pregnancy, chronic pulmonary heart disease, liver cirrhosis and ascites, and less frequently with renin-secreting renal tumor. Secondary hyperaldosteronism is diagnosed less frequently than primary, and both primary and secondary hyperaldosteronism are more common in women, between ages 30 and $60(5,6)$.

\section{CASE REPORT}

A 62-year-old patient reported for cardiologist examination due to frequent blood pressure spikes of up to $185 / 120 \mathrm{mmHg}$. Hypertensive reactions were accompanied by nausea, numbness of the lips and part of the face, tremors and tachycardia. This was a hypotensive woman in whom elevated blood pressure values had first been measured around the age of 25 , after pregnancy. At that time, she was not examined for secondary hypertension. She reported a positive family history (father and mother were treated for hypertension in their youth).

Lung examination findings imply normal breath sounds, without an accompanying finding, rhythmic heartbeat, clear tones, mild systolic regurgitant murmur at the mitral orifice $2 / 6$, Blood pressure $120 / 80 \mathrm{mmHg}$. Objectively, the woman is normally nourished, BMI $20 \mathrm{~kg} / \mathrm{m} 2$. The ECG showed sinus rhythm, normogram, fr:72 / min, no heart rhythm disturbances, no ST-T dynamics. An ergometric stress test was carried out and was negative for myocardial ischemia at reached SMF. Echocardiographic examination of the heart showed a normal size left ventricle EDD $45 \mathrm{~mm}$, ESD $29 \mathrm{~mm}$, preserved global contractile function, EF: 65\% (from 2D according to Simpson), without segmental deficits in contractility. Myocardial thickness was normal. Transmitral flow indicated a slightly slowed diastolic relaxation e/A 0.60 $\mathrm{m} / \mathrm{s}$. The anterior mitral valve was longer, more hypermobile, with mild holosystolic prolapse, the posterior mitral valve had mild prolapse. Cusps were without signs of myxomatous alteration. Moderate mitral regurgitation 2+ was registered. The aorta was of normal lumen width. The aortic valve was trivelar, the velums were of preserved separations. The flow at aortic orifice was of preserved velocity. The left atrium was of normal size. The right heart cavities were of normal size. Mild tricuspid valve prolapse was registered. Mild tricuspid regurgitation 1+ was registered. Right ventricle systolic pressure was preserved. The pulmonary artery was of normal lumen width, preserved flow, observed bifurcation, trace PR. The pericardium was of normal reflected echo intensity, without delamination and without effusion.

At 48-h ambulatory blood pressure monitoring, the average arterial pressure was 103/64 mmHg (SF: 64/min), 107/68 mmHg (SF:67 / min) during the awake period, and 93/55 $\mathrm{mmHg}$ (SF:58 / min) during the sleep period. The mean arterial pressure was $82 \mathrm{mmHg}(86 \mathrm{mmHg}$ during the day and $73 \mathrm{mmHg}$ during the night). The average value of pulse pressure was $39 \mathrm{mmHg}$ ( $39 \mathrm{mmHg}$ during the day and 38 $\mathrm{mmHg}$ during the night). The maximum measured blood pressure values were $134 / 89 \mathrm{mmHg}(9 \mathrm{pm}) 150 / 102 \mathrm{mmHg}$ $(12: 30 \mathrm{am})$ during the awake and sleep periods, respectively. The circadian rhythm was preserved.

The patient was referred to an endocrinologist to be examined for secondary hypertension. In laboratory analyzes, renin was elevated, 186.2 (reference values up to 39.9), and aldosterone was elevated, 20.1 (reference values up to 15.75). Other parameters of adrenal function, ACTH, cortisol, adrenaline, noradrenaline, dopamine, were within normal limits. Also metanephrine, normetanephrine, urine VMA were within physiological limits. Thyroid hormones TSH, T3, T4 were within normal range. Slightly lower values of potassium 3.3 (reference values 3.5-5.5), sodium 131 (reference values 136-148) and chloride 91 (reference values 98-107) were also registered.

Renal Artery Doppler as well as MSCT of the endocranium and lungs were within physiological limits. Abdominal ultrasound showed a minor oval, clearly delineated hypoechoic change $10 \mathrm{~mm}$ in size in the left adrenal gland, which most likely corresponds to an adenoma.

However, abdomen MSCT showed up to $8 \mathrm{~mm}$ hyperplasia of the left adrenal gland medial section, dominated by fat content (Figure 1). 


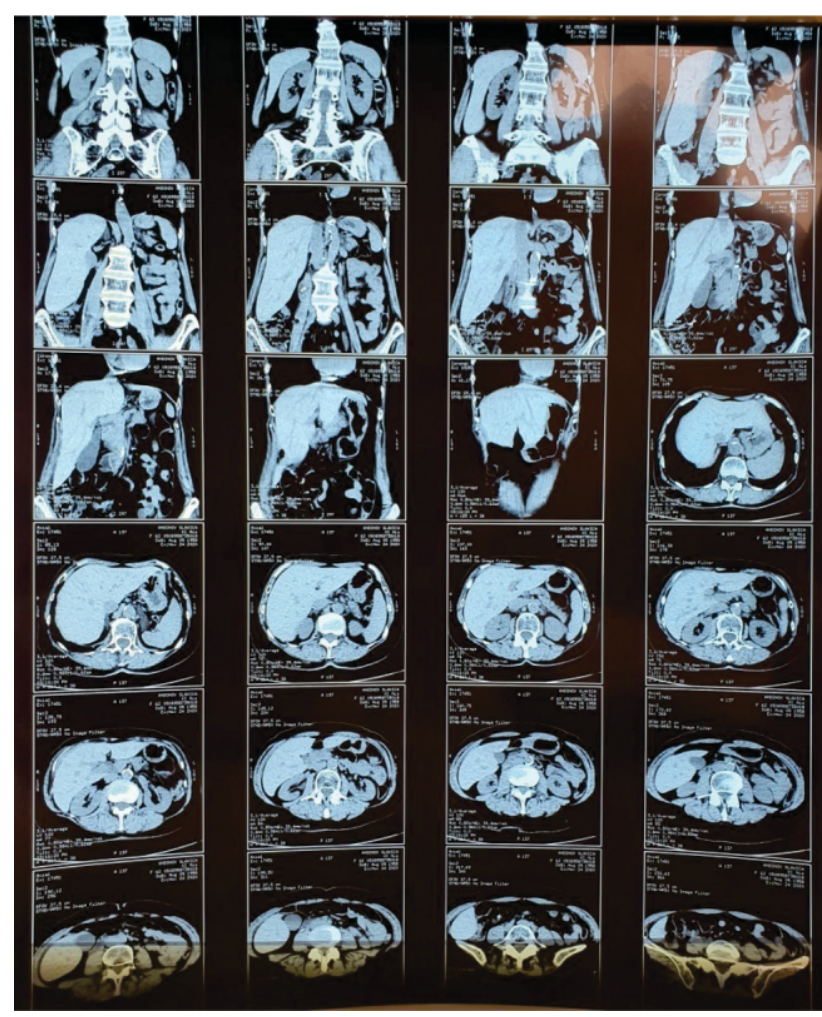

Figure 1. Hyperplasia of the left adrenal gland

Complete diagnostic procedure determined it was unilateral adrenal hyperplasia of the left adrenal gland with suspected secondary hyperaldosteronism. At endocrine surgeon examination, surgical treatment of the adrenal gland was not indicated, and monitoring (MSCT or MR of the abdomen) and drug therapy were suggested.

The patient's therapy comprising Spirinolactone $1 \times 25$ $\mathrm{mg}$, Lisinopril 1x10mg, Concor 1x5 mg and saltier diet shows satisfactory blood pressure regulation and electrolyte status normalization. Introduced therapy has normalized blood pressure and improved the subjective feeling of the patient. Hypertensive crises have not been registered in the further course of treatment.

\section{DISCUSSION}

Excessive aldosterone secretion is the most common cause of secondary endocrine hypertension. According to some recent studies, it is a much more common cause of hypertension than previously thought, with a prevalence of $10 \%$ in the general hypertensive population, and occurs in about $20 \%$ of patients with resistant hypertension (7). Complete diagnostic processing should be carried out in case of stage II and III hypertension, hypertension that does not respond well to medical treatment, hypertension with spontaneous hypokalemia or diuretic-induced hypokalemia, hypertension with adrenal incidentaloma, hypertension and family history of early-onset hypertension (8).

Complications of excessive aldosterone secretion include atrial fibrillation, myocardial infarction, myocardial fibrosis, left ventricular hypertrophy, stroke, as well as increased cardiovascular mortality $(9,10)$. Patients with hyperaldosteronism and secondary hypertension have higher cardiovascular morbidity and mortality as compared to patients with essential hypertension of the same stage, sex and age. Also, long-term exposure to elevated adosterone levels can result in significant cardiovascular damage, regardless of the blood pressure level. These results have prompted further, significant research in this field aimed at finding specific therapeutic options $(11,12)$.

Treatment with mineralocorticoid receptor inhibitors, i.e. spirinolactone, is the first-line therapy. Eplerenone is considered in spironolactone intolerance, gynecomastia in men and menstrual disorders in women (13). Spironolactone and eplerenone-intolerant patients are administered amiloride and triamterene. Calcium antagonists, ACE inhibitors or angiotensin II receptor antagonists as well as doxazosin can be combined with mineralocorticoid receptor inhibitors to better regulate blood pressure $(14,15,16)$.

When administration of several antihypertensive drugs shows no results in controlling blood pressure and hypokalemia, surgical treatment is indicated. In unilateral adrenal hyperplasia, unilateral adrenalectomy, preferably laparoscopically, is the method of choice with a very high success rate in controlling blood pressure and potassium values postoperatively (17).

\section{CONCLUSION}

This paper aims to indicate that the examination for secondary endocrine hypertension should be carried out in mid-life age as well, especially if there are atypical anamnestic data about sudden blood pressure spikes. If tension is normalized with medications, and there is no damage to other target organs, then adrenal hyperplasia surgical treatment, which is the most common type of treatment, is postponed until further notice.

\section{REFERENCES}

1. Isabella Sudano, Felix Beuschlein and Thomas F. Lüscher. Secondary causes of hypertension. Oxford University Press. 2019.

2. Lesley Charles, Jean Triscott and Bonnie Dobbs. Secondary Hypertension: Discovering the Underlying Cause. Am Fam Physician. 2017; 96 (7): 453-61.

3. DominguezA, Muppidi V and Gupta S. Hyperaldosteronism. StatPearls. 2020.

4. Hang Shen, Zhi-XinXu and Qi-Fu Li. New advances in the diagnosis of primary aldosteronism. Chronic Disease and Translational Medicine. Vol. 6 (1), 2020, 1-5.

5. Ashley B. Grossman. Secondary aldosteronism. 2020.

6. Papadopoulou-Marketou N, Vaidya A, Dluhy R, et al. Hyperaldosteronism. MDText.com, Inc., South Dartmouth (MA). 2020. 
7. Wang, Wei MD; Wei, Feng; Li, Ran Hao; Tian, JiaHui. A case report of idiopathic hyperaldosteronism characterized by bilateral adrenal adenoma. Medicine (Baltimore). 2019; 98 (43): e17418.

8. Like Zhao, Wei Liu , Xue Yu , Hongyi Li. A 100-year old patient presented with profound diuretic-induced hypokalemia as first indicator of primary aldosteronism: a case report. Int J ClinExp Med 2016; 9 (6):12361-12364.

9. Ryo Nakamaru , Koichi Yamamoto, Satoko Nozatoet al. A case of primary aldosteronism with resistant hypertension successfully treated by unilateral adrenalectomy after unsuccessful classification of subtype in adrenal venous sampling. Clin Case Rep. 2019; $22 ; 7$ (10): 1895-1899.

10. Gary S Francis, W H Wilson Tang. Should we consider aldosterone as the primary screening target for preventing cardiovascular events? Journal of the American College of Cardiology. 2005; 45 (8): 1249-1250.

11. Cristiana Catena, GianLuca Colussi, Elisa Nadalini et al. Cardiovascular Outcomes in Patients With Primary Aldosteronism After Treatment. Arch Intern Med. 2008; 168 (1): 80-85.

12. Fathimah M, Gunavathy M, Nadzimah. A Case of Resistant Hypertension Secondary to Primary Aldosteronism. Clinical Medicine and Diagnostics 2014; 4 (4): 61-64.

13. Andjelkovic Zoran. Primary hyperaldosteronism: diagnostic proseduere and treatment. Bulletin of the Institute of thyroid gland and metabolism "Zlatibor". 2003, vol. 6 (7), 37-48.

14. Sujit Vakkalanka, Andrew Zhao, Mohammed Samannodi. Primary hyperaldosteronism: a case of unilateraladrenal hyperplasia with contralateral incidentaloma. BMJ Case Rep 2016.

15. Benjamin Lechner, Katharina Lechner, Daniel Heinrich et al. Medical treatment of primary aldosteronism. European Journal of Endocrinology. 2019; 181 (4): 147-153.

16. Novakovic T, Pajovic S.: Endocrinology, Kosovska Mitrovica, 2010.

17. Brian K P Goh, Yeh-Hong Tan, Kenneth T E Chang et al. Primary hyperaldosteronism secondary to unilateral adrenal hyperplasia: an unusual cause of surgically correctable hypertension. World J Surg. 2007; 31(1): 72-79. 